\title{
Studi Keperilakuan Wajib Pajak Orang Pribadi Usahawan Terhadap Kepatuhan Perpajakan Di Palangka Raya
}

\author{
Sifera Patricia Maithy, Sutrisno, Bambang Hariadi \\ Fakultas Ekonomi dan Bisnis, Universitas Brawijaya \\ Email korenpondensi: sifera8@gmail.com
}

\begin{abstract}
This study aims to examine the taxpayer compliance behavior of individuals on all tax obligations. The influencing factors are attitude, subjective norm, perceived behavioral Control, and tax knowledge mediated by intention to comply. This research is the development of tax compliance model from previous research. The data of this study was obtained from 160 respondents of individual entrepreneur taxpayers listed in the Small Taxpayers Office of Palangka Raya. Data is processed using SmartPLS 3.0. The results of this study obtained empirical evidence that attitudes on taxes, subjective norms, perceptual behavior control, tax knowledge, and intention to obediently affect taxpayer compliance personal taxpayer. This research also supports the theory of planned behavior and social learning theory.
\end{abstract}

Keywords: Tax compliance, Intention to comply, Personal taxpayers

Saran sitasi: Maithy, S., Sutrisno, S., \& Hariadi, B. (2019). Studi Keperilakuan Wajib Pajak Orang Pribadi Usahawan Terhadap Kepatuhan Perpajakan. Jurnal Akuntansi dan Pajak, 19(2),108-115. doi:http://dx.doi.org/10.29040/jap.v19i2.279

DOI: http://dx.doi.org/10.29040/jap.v19i2.279

\section{Pendahuluan}

Penerimaan pajak adalah sumber terbesar dalam pembiayaan pembangunan di Indonesia. Dalam upaya peningkatan penerimaan pajak maka perlu ditingkatkan kepatuhan pajak. Upaya untuk meningkatkan pendapatan pajak salah satunya dengan menjangkau wajib pajak baru. Dalam rangka meningkatkan dan memaksimalkan pendapatan pajak perlu meningkatkan kepatuhan wajib pajak untuk membayar kewajiban pajak mereka.

Kepatuhan pajak terjadi jika wajib pajak membayar tepat waktu, menghitung pajak secara akurat sesuai dengan aturan perpajakan (James \& Alley, 2002). Singh dan Bhupalan (2001) memberikan perspektif yang lebih luas dalam kepatuhan pajak. Perspektif yang lebih luas dari kepatuhan pajak membutuhkan tingkat kejujuran, pengetahuan pajak yang memadai dan kemampuan untuk menggunakan pengetahuan, ketepatan waktu, akurasi, dan catatan yang memadai untuk menyelesaikan pajak. Kepatuhan wajib pajak menjadi pusat dalam sistem perpajakan karena Indonesia menggunakan self assessment system.

Di Indonesia, self assessment system memberikan kepercayaan penuh kepada wajib pajak untuk melaksanakan hak dan kewajiban pajak mereka, sehingga kesadaran Wajib Pajak untuk melaksanakan kewajiban perpajakannya mutlak diperlukan (Damayanti \& Supramono, 2012). Permasalahan yang terjadi menurut Tarjo \& Kusumawati (2006) yaitu masih banyak Wajib Pajak yang belum memahami bagaimana 
menghitung kewajiban pajak mereka dan beberapa dari mereka cenderung sengaja melanggar aturan pajak.

Fenomena di Indonesia berdasarkan persentase realisasi penerimaan pajak dan rasio kepatuhan penyampaian SPT Tahunan menunjukkan tingkat kepatuhan wajib pajak masih sangat rendah. Berdasarkan sasaran strategis Dirjen Pajak dengan tingkat kepatuhan wajib pajak yang tinggi, diharapkan nantinya akan berbanding lurus dengan tingkat penerimaan pajak.

Berdasarkan persentase realiasi penerimaan pajak tahun 2013 capaian sebesar $92,57 \%$, tahun 2014 capaian sebesar 91,56\%, tahun 2015 sebesar 81,96\% dan tahun 2016 capaian sebesar 81,60\% (www.pajak.go.id, 2016). Meskipun persentase penerimaan pajak dari target selama tiga tahun terakhir mengalami penurunan, namun penerimaan pajak (termasuk PPh Migas) tahun 2014-2015 mengalami pertumbuhan sebesar 7,68\% dan tahun 2015-2016 sebesar 4,24\%. Kinerja penerimaan pajak tahun 2016, ditopang oleh penerimaan dari Amnesti Pajak periode I dan II tahun 2016 yang berhasil menghimpun uang sebesar Rp104,67 triliun. Namun, jika termasuk penerimaan dari tunggakan pajak yang dibayar dan realisasi hasil pemeriksaan bukti permulaan, maka jumlah total penerimaan Amnesti Pajak sebesar Rp109,5 triliun.

Fenomena yang ada saat ini adalah adanya gap antara target dan realisasi penerimaan pajak yang tinggi dengan realita bahwa kepatuhan wajb pajak di Indonesia masih tergolong rendah. Salah satu indikator untuk mengetahui rendahnya tingkat kepatuhan wajib pajak adalah rasio kepatuhan SPT Tahunan. Pencapaian rasio kepatuhan penyampaian SPT Tahunan PPh tahun 2013 sampai dengan 2016, secara realisasi terdapat kenaikan realisasi pajak setiap tahunnya. Kecuali pada tahun 2014 realisasi rasio kepatuhan mengalami penurunan. Meskipun terjadi kenaikan setiap tahunnya, capaian rasio kepatuhan masih berada di bawah target yang telah ditetapkan dengan berdasarkan target yang tercantum dalam Rencana Strategi (Renstra)
Kemenkeu 2015-2019 dimana setiap tahunnya mendapat kenaikan target sebesar $2,25 \%$ dari $70 \%$ di tahun 2015 hingga $80 \%$ di tahun 2019 (www.pajak.go.id, 2016).

Dari fenomena kepatuhan pajak yang terjadi di Indonesia, maka perlu mengekplorasi pendekatan faktor-faktor non-ekonomi yang mempengaruhi perilaku pembayar pajak (James, Murphy, \& Reinhart, 2005). Fokus dalam menciptakan kepatuhan pajak melalui pendekatan psikologis sosial yang dipandang memberikan pemahaman yang lebih baik tentang perilaku wajib pajak (Pope \& Mohdali, 2010), dalam mempertimbangkan faktor-faktor non-ekonomi. Salah satu teori yang menjelaskan aspek psikologis seseorang dan sering dijadikan rujukan penelitian di bidang keperilakuan dalam rangka menjelaskan tentang mengapa seseorang berperilaku tertentu adalah Teori Perilaku Terencana (Theory of Planned Behaviour) dan Teori Pembelajaran Sosial (Social Learning Theory) .

Teori Perilaku Terencana adalah model berbasis niat yang dikembangkan oleh Ajzen (1991) menjelaskan maksud seseorang untuk melakukan perilaku tertentu. Teori Perilaku Terencana merupakan teori yang dibangun untuk memprediksi dan memahami pengaruh sikap dan motivasi pada perilaku yang bukan di bawah kontrol individu (Ajzen, 2005). Teori Perilaku Terencana ini telah merambah ke berbagai bidang termasuk perpajakan. Penelitian tentang kepatuhan pajak di berbagai negara telah berusaha membuktikan secara empiris teori ini di bidang perpajakan. Trivedi, Shehata, dan Mastelman (2005) secara empiris Teori Perilaku Terencana di Kanada. Bobek dan Hatfield (2003) meneliti hal yang sama di Amerika. Benk, Budak dan Cakmak (2012) meneliti di Turki. Langham, Paulsen, dan Hartel (2012), menguji kepatuhan pajak dengan menggunakan Teori Perilaku Terencana di Australia.

Di Indonesia sendiri telah banyak yang melakukan penelitian dibidang perpajakan dengan menggunakan kerangka Teori Perilaku Terencana, beberapa diantaranya adalah 
Damayanti, Sutrisno, Subekti dan Baridwan (2015). Dalam penelitian Bobek dan Hatfield (2003), Damayanti et al. (2015) berhasil membuktikan secara empiris bahwa sikap, norma subjektif, dan kontrol perilaku persepsian merupakan variabel yang mempengaruhi niat untuk patuh. Berdasarkan penelitian Benk et al. (2012) tidak dapat membuktikan secara empiris bahwa sikap berpengaruh positif terhadap niat untuk patuh. Trivedi et al. (2005) dan Langham et al. (2012) juga tidak dapat membuktikan secara empiris bahwa kontrol perilaku persepsian berpengaruh positif terhadap niat untuk patuh.

Penelitian lainnya yang meneliti tentang kepatuhan pajak adalah Teori Pembelajaran Sosial, yaitu seseorang dapat belajar lewat pengamatan dan pengalaman langsung (Bandura, 1977). Teori Pembelajaran Sosial meliputi proses perhatian, proses penahanan, proses reproduksi motorik dan proses penguatan. Dalam konteks perpajakan, Teori Pembelajaran Sosial ini sangat relevan untuk menjelaskan perilaku dari pelakupelaku perpajakan dikarenakan peneliti dapat mengetahui pengaruh pengetahuan pajak terhadap kepatuhan wajib pajak.

Penelitian Andreas dan Savitri membuktikan bahwa ada pengaruh positif pengetahuan pajak terhadap kepatuhan pajak. Pada gilirannya, pengetahuan yang lebih baik tentang perpajakan akan menyebabkan kepatuhan pajak yang lebih baik. Hasil penelitan Nurhayati dan Halimatusadiah (2015) memberikan hasil yang berbeda yaitu tidak dapat membuktikan pengaruh pengetahuan pajak terhadap kepatuhan pajak, oleh karena itu pengetahuan pajak dari wajib pajak tidak mencerminkan kesadaran mereka dan kesediaan untuk melakukan kewajibannya.

Penelitian ini mengacu pada penelitian Damayanti et al. (2015). Perbedaan penelitian ini dengan penelitian sebelumnya yaitu terletak pada lokasi yang digunakan dalam penelitian yaitu Kota Palangka Raya dipilih karena sebagai pusat pembangunan dan usaha di Provinsi Kalimantan Tengah.
Provinsi Kalimanan Tengah yang selama ini dikenal mengandalkan 14 daerah kabupaten/kota sebagai penyangga ekonomi. Kalimantan Tengah menyerap sebanyak $84 \%$ tenaga kerja di luar pertanian. Berdasarkan lapangan usaha, perdagangan besar dan eceran memiliki kontribusi usaha sebesar $48,40 \%$ dari seluruh aktivitas ekonomi. Kontribusi usaha lain berasal dari penyediaan akomodasi, makan/minum sebesar $15,11 \%$ dan usaha industri pengolahan berperan sebesar 9,77\% (kalteng.bps.go.id).

Penelitian ini mengembangkan Teori Perilaku Terencana dikarenakan ketidakkonsistenan hasil dari berbagai penelitiam sebelumnya. Maka penelitian ini menambahkan pengetahuan pajak sebagai variabel independen yang dibangun dari Teori Pembelajaran Sosial. Pengetahuan pajak merupakan hal yang dipertimbangkan dalam meningkatkan kepatuhan pajak.

\section{Metode Penelitian}

Responden yang berasal dari masyarakat pengguna jasa akuntan publik, untuk pihak internal pengguna laporan keuangan akan diwakili olehdirektur atau manajer beberapa perusahaan go publik yang terdaftar di Bursa Efek Indonesia (BEI) di kota Makassar. Untuk pihak eksternal pengguna laporan keuangan kreditor akan diwakili oleh kepala cabang bankbank konvensional dan pihak investor akan diwakilioleh perusahaan sekuritas yang berada di kota Makassar. Adapun waktu penelitian sekitar 10 (sepuluh) bulan yang berlangsung dari bulan Maret sampai dengan Desember 2017.

Penelitian ini merupakan penelitian eksplanatori. Populasi dalam penelitian ini adalah wajib pajak orang pribadi kategori usahawan (memiliki NPWP) dan melakukan pekerjaan bebas yang berdomisili diwilayah Palangka Raya yang terdaftar di KPP Pratama Palangka Raya, karena wajib pajak usahawan dan melakukan pekerjaan bebas melakukan semua kewajiban perpajakan mulai dari menghitung beban pajak, membayar pajak yang telah dihitung, dan melaporkan pajak yang telah dihitung dan dibayar. Pemilihan 


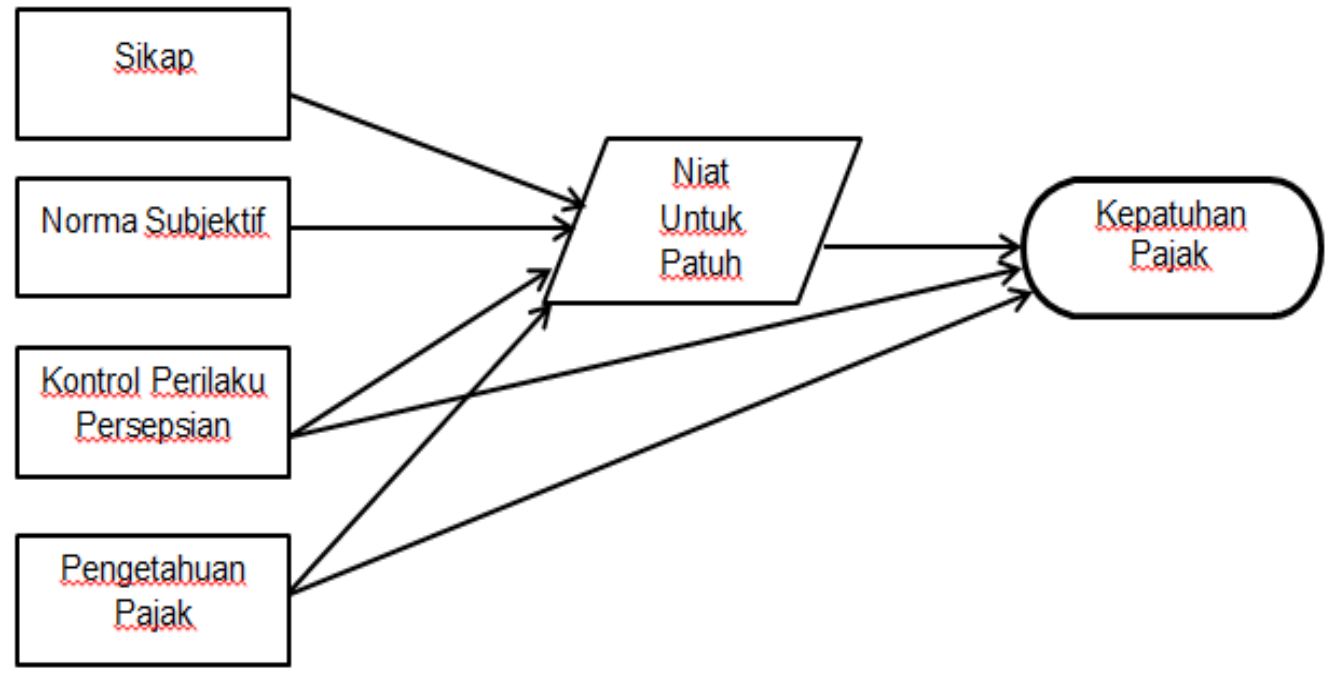

Gambar 1. Model Penelitian

Tabel 1. Hasil Analisis

\begin{tabular}{ccccc}
\hline Hipotesis & Konstruk & Original Sampel & T-statistic & Keputusan \\
\hline $\mathrm{H} 1$ & $\mathrm{SKP} \rightarrow \mathrm{NP}$ & 0,158 & 3,571 & Diterima \\
$\mathrm{H} 2$ & $\mathrm{NS} \rightarrow \mathrm{NP}$ & 0,394 & 7,579 & Diterima \\
$\mathrm{H} 3$ & $\mathrm{KPP} \rightarrow \mathrm{NP}$ & 0,189 & 3,400 & Diterima \\
$\mathrm{H} 4$ & $\mathrm{KPP} \rightarrow \mathrm{KP}$ & 0,160 & 2,875 & Diterima \\
$\mathrm{H} 5$ & $\mathrm{PP} \rightarrow \mathrm{NP}$ & 0,237 & 4,794 & Diterima \\
$\mathrm{H} 6$ & $\mathrm{PP} \rightarrow \mathrm{KP}$ & 0,356 & 4,626 & Diterima \\
$\mathrm{H} 7$ & $\mathrm{NP} \rightarrow \mathrm{KP}$ & 0,367 & 4,745 & Diterima \\
\hline
\end{tabular}

Sumber: Data Primer Diolah (2018)

sampel yang digunakan dalam penelitian ini adalah convenience sampling karena peneliti tidak mengetahui jumlah spesifik populasi wajib pajak orang pribadi kategori usahawan yang terdaftar di KPP Pratama Palangka Raya. Jumlah sampel minimal yang menjadi syarat pada SEMPLS adalah sebanyak sepuluh kali jumlah jalur (Sholihin \& Ratmono, 2013). Adapun model penelitian sebagaimana Gambar 1.

Penelitian ini terdapat 7 jalur dalam model penelitian ini, sehingga jumlah minimal sampel yang dibutuhkan pada penelitian ini adalah 70 responden. Karena jumlah tersebut merupakan minimal untuk penentuan jumlah sampel, maka peneliti akan mengkalikan 3 sehingga jumlah sampel 210 responden, dikarenakan besarnya sampel dalam suatu penelitian bila terlalu besar akan menyulitkan peneliti untuk bisa mendapatkan model penelitian yang cocok sehingga disarankan ukuran sampel yang sesuai berkisar antara 100-200 responden agar dapat digunakan estimasi interpretasi dengan Structural Equation Modelling (Abdillah \& Hartono, 2015). Penelitian ini menggunakan metode analisis PLS (Partial Least Square) dengan alat analisis smartPLS 3.0.

\section{Hasil dan Pembahasan}

\subsection{Hasil penelitian}

Sebanyak 160 responden mengisi kuisioner penelitian ini. Hasil analisis hipotesis masingmasing jalur yang diperoleh dari hasil analis menggunakan software smartPLS 3.0 adalah sebagai mana Tabel 1.

\subsection{Pembahasan}

Berdasarkan hasil pengujian hipotesis $\mathrm{H} 1, \mathrm{H} 2$, H3, H4, H5, H6, dan H7 memiliki nilai tstatistics $>1.96$ dan nilai $p$-values $<0.05$, maka dinyatakan signifikan, sehingga dapat disimpulkan bahwa hipotesis diterima. 
Hipotesis satu menyatakan bahwa sikap wajib pajak terhadap kepatuhan pajak berpengaruh positif terhadap niat untuk patuh. Hasil penelitian ini konsisten dengan penelitian yang dilakukan oleh Bobek dan Hatfield (2003), dan Damayanti et al. (2015). Dengan demikian, disimpulkan bahwa sikap merupakan faktor determinan niat untuk patuh. Bukti empiris ini memiliki implikasi bahwa wajib pajak yang memiliki sikap atas kepatuhan pajak yang lebih positif akan lebih berniat untuk patuh atas kewajiban perpajakan mereka dibanding wajib pajak yang memiliki sikap atas kepatuhan pajak yang negatif. Dengan demikian, upaya dalam membentuk sikap positif wajib pajak orang pribadi di Palangka Raya. Aparat perpajakan gencar melakukan sosialisasi manfaat perpajakan dalam membantu perekonomian Negara. Sosialisasi ini melalui media langsung maupun media sosial sebagai sarana informasi dan komunikasi.

Hipotesis dua menyatakan bahwa bahwa norma subjektif berpengaruh positif terhadap niat untuk patuh. Hasil penelitian ini konsisten dengan penelitian yang dilakukan oleh Bobek dan Hatfield (2003) dalam penelitiannya terhadap Wajib Pajak di Amerika Serikat dan Damayanti et al. (2015) di Indonesia. Norma subjektif merujuk pada tekanan lingkungan sekitar kepada wajib pajak bahwa kepatuhan adalah sebuah keharusan. Dengan demikian, pembuat kebijakan seharusnya berupaya menciptakan kondisi masyarakat di sekitar wajib pajak mendukung kepatuhan pajak. Norma sosial dibangun melalui tekanan sosial dan pengaruh orang-orang sekitar wajib pajak yang dianggap penting oleh individu tersebut, misalnya keluarga, relasi, dan pimpinan (Basri, Surya, Fitriasari, Novriyan, \& Tania, 2012). Pengaruh norma subjektif disebabkan karena budaya masyarakat Palangka Raya yang suka nergaul dan berinteraksi soaial sehingga lingkungan tersebut mempengaruhi keinginan wajib pajak untuk patuh pajak.

Hipotesis tiga menyatakan bahwa. kontrol perilaku persepsian berpengaruh positif terhadap niat untuk patuh. Hasil penelitian ini konsisten dengan hasil penelitian yang dilakukan oleh Bobek dan Hatfield (2003), Benk et al. (2012), Damayanti et al. (2015). Hasil penelitian ini membuktikan bahwa kontrol perilaku persepsian mempengaruhi niat untuk patuh. Bukti empiris ini memiliki implikasi bahwa wajib pajak yang memiliki kontrol perilaku persepsian yang lebih tinggi akan lebih berniat untuk patuh atas kewajiban perpajakan. Kontrol perilaku persepsian yang lebih tinggi berarti bahwa wajib pajak memiliki keyakinan yang tinggi bahwa kepatuhan pajak mudah untuk ditampilkan. Upaya peningkatan yang dilakukan adalah aparatur perpajakan seyogyanya menciptakan peraturan yang mempemudah untuk menampilkan niat untuk patuh, yaitu dengan menanamkan kepercayaan pada persepsi wajib pajak terhadap petugas pajak sehingga proses pemenuhan kewajiban perpajakan tidak dipersulit, dapat dipahami sehingga wajib pajak dapat melaksanakan kewajiban perpajaknnya dengan baik dan disiplin.

Hipotesis empat menyatakan bahwa kontrol perilaku persepsian berpengaruh terhadap perilaku kepatuhan pajak. Hasil ini memperkuat hasil penelitian yang dilakukan oleh Bobek dan Hatfield (2003), Langham et al. (2012), Damayanti et al. (2015). Hasil penelitian ini membuktikan bahwa kontrol perilaku persepsian mempengaruhi kepatuhan pajak. Bukti empiris ini memiliki implikasi bahwa wajib pajak yang memiliki kontrol perilaku persepsian yang lebih tinggi akan lebih patuh atas kewajiban perpajakan dikarenakan memiliki keyakinan yang tinggi bahwa kepatuhan pajak mudah untuk ditampilkan. Dalam rangka mempertahankan keyakinan tersebut, maka peraturan yang mempermudah untuk menampilkan niat untuk patuh diperkuat melalui mekanisme equaliasi dan pelaporan pihak ketiga, penerapan sanksi dan kemungkina pemeriksaan. Dari upaya ini mempermudah aparatur perpajakan dalam melakukan pekerjaannya sehingga optimal dalam melayani wajib pajak.

Hipotesis lima menyatakan bahwa pengetahuan pajak berpengaruh positif terhadap niat 
untuk patuh. Hasil penelitian ini konsisten dengan penelitian yang dilakukan oleh Ward, Ward dan Wilson (1996), Damayanti dan Supramono (2012). Bukti empiris ini memiliki implikasi bahwa wajib pajak yang memiliki pengetahuan pajak yang lebih baik akan lebih berniat untuk patuh atas kewajiban perpajakan mereka dibanding wajib pajak yang belum memiliki pengetahuan perpajakan. Pengetahuan pajak adalah informasi pajak yang digunakan wajib pajak sebagai dasar untuk bertindak, seperti mengambil keputusan, dan menempuh arah atau strategi sehubungan dengan pelaksanaan hak dan kewajibannya di bidang perpajakan (Carolina \& Simanjuntak, 2011). Pengetahuan perpajakan masyarakat di Palangka Raya dapat melalui pendidikan perpajakan formal atau non formal sehingga meningkatkan pemahaman wajib pajak sebagai wujud gotong royong dalam pembangunan nasional

Hipotesis enam menyatakan bahwa pengetahuan pajak berpengaruh positif terhadap kepatuhan pajak. Hal ini berarti semakin baik pengetahuan pajak maka perilaku kepatuhan pajak maka semakin tinggi. Hasil penelitian ini konsisten dengan penelitian yang dilakukan oleh Niemirowski, Baldwin, dan Wearing (2013) di Australia. Penelitian di Indonesia yaitu Andreas dan Savitri (2015) dan Puspita, Subroto, dan (2016). Bukti empiris ini memiliki implikasi bahwa wajib pajak yang memiliki pengetahuan pajak yang lebih baik akan memiliki perilaku pajak yang baik pula. Supramono dan Damayanti (2009) menjelaskan bahwa seseorang akan taat membayar pajak tepat pada waktunya, jika lewat pengamatan dan pengalaman langsungnya, hasil pungutan pajak itu telah memberikan kontribusi nyata pada pembangunan diwilayahnya. Oleh sebab itu, dalam rangka meningkatkan kepatuhan pajak maka upaya peningkatan pengetahuan pajak dapat dilakukan berkelanjutan dan terus berinovasi sehingga meningkatkan pemahaman dan mendewasakan wajib pajak melalui pengajaran dan pelatihan sehingga akan terus memiliki perilaku yang patuh akan kewajiban perpajakannya.
Hipotesis tujuh menyatakan bahwa niat untuk patuh berpengaruh positif terhadap kepatuhan pajak. Hal ini berarti semakin maka semakin tinggi niat patuh maka perilaku kepatuhan pajak akan semakin tinggi. Hasil penelitian ini sejalan dengan hasil penelitian yang dilakukan oleh Trivedi et al. (2005), Langham et al. (2012), Damayanti et al. (2015). Bukti empiris ini memiliki implikasi bahwa wajib pajak yang memiliki niat untuk patuh lebih besar akan memiliki perilaku kepatuhan pajak yang lebih besar pula. Ajzen (1991) menjelaskan niat sebagai sejauh mana seorang individu bersedia berusaha keras untuk melakukan perilaku, atau usaha yang direncanakan untuk mengerahkan tindakan guna melaksanakan perilaku. Dengan demikian, dapat disimpulkan bahwa niat untuk patuh merupakan faktor determinan perilaku kepatuhan pajak

\section{Kesimpulan}

Dalam pengujian terhadap wajib pajak orang pribadi di Palangka Raya, menunjukkan bahwa kepatuhan wajib pajak orang pribadi kategori usahawan di KPP Pratama Palangka Raya meningkat karena sikap yang positif, norma subjektif yang kuat, kontrol perilaku persepsian yang tinggi dan pengetahuan pajak yang baik, kemudian didukung oleh niat untuk patuh yang kuat.

Melalui penelitian ini dapat disimpulkan bahwa Teori Perilaku Terencana dan Teori Pembelajaran Sosial adalah teori yang dapat digunakan untuk menjelaskan perilaku kepatuhan pajak. Hasil penelitian ini menunjukkan hubungan sikap, norma subjektif dan kontrol perilaku persepsian terhadap niat untuk patuh berdasarkan Teori Perilaku Terencana dan pengetahuan pajak terhadap kepatuhan pajak berdasarkan Teori Pembelajaran Sosial.

Hasil penelitian ini mendukung penelitian sebelumnya, disebabkan karena karakteristik responden mayoritas berusia muda, memiliki latar belakang pendidikan S1 serta lama usaha responden dalam menjalankan usaha. Sehingga dapat dikatakan bahwa responden di Palangka 
Raya telah terbiasa, mampu, tanggap, dan memahami dalam melaksanakan proses kewajiban perpajakannya.

Penelitian ini juga membuktikan secara empiris bahwa niat untuk patuh, kontrol perilaku persepsian dan pengetahuan pajak berpengaruh terhadap perilaku kepatuhan wajib pajak orang pribadi di Palangka Raya. Penelitian ini memberikan hasil bahwa niat untuk patuh merupakan faktor penentu perilaku kepatuhan perpajakan sebagai variabel mediasi. Niat untuk patuh mengindikasikan bahwa wajib pajak orang pribadi mempunyai hasil evaluasi yang positif terhadap perilaku dalam memenuhi kewajiban perpajakannya

\section{Ucapan Terimakasih}

Penulis mengucapkan terima kasih kepada Fakultas Ekonomi dan Bisnis, Universitas Brawijaya yang telah mendukung selesainya penelitian ini.

\section{Daftar Pustaka}

Abdillah, W., \& Hartono, J. (2015). Partial Least Square (PLS): alternatif structural equation modeling (SEM) dalam penelitian bisnis. Yogyakarta: Penerbit Andi.

Ajzen, I. (1991). The theory of planned behavior. Organizational behavior and human decision processes, 50(2), 179-211.

Ajzen, I. (2005). Attitudes, personality, and behavior. McGraw-Hill Education (UK).

Andreas \& Savitri, E. (2015). The Effect of Tax Socialization, Tax Knowledge, Expediency of Tax ID Number and Service Quality on Taxpayers Compliance with Taxpayers Awareness as Mediating Variables. Procedia-social and behavioral sciences, 211, 163-169.

Badan Pusat Statistik Provinsi Kalimantan Tengah. (2016). Diakses 20 Mei 2018, dari https://kalteng.bps.go.id/

Bandura, A. (1977). Self-efficacy: toward a unifying theory of behavioral change. Psychological review, 84(2), 191.

Basri, Y. M., Surya, R. A. S., Fitriasari, R., Novriyan, R., \& Tania, T. S. (2012). Studi Ketidakpatuhan Pajak: Faktor yang Mempengaruhinya (Kasus pada Wajib pajak
Orang Pribadi yang terdaftar di KPP Pratama Tampan Pekanbaru). Simposium Nasional Akuntansi, 15.

Benk, S., Budak, T., \& Cakmak, A. F. (2012). Tax professionals'perceptions of tax fairness: survey evidence in turkey. International Journal of Business and Social Science, 3(2).

Bobek, D. D., \& Hatfield, R. C. (2003). An investigation of the theory of planned behavior and the role of moral obligation in tax compliance. Behavioral Research in Accounting, 15(1), 13-38.

Carolina, V., \& Simanjuntak, T. H. (2011). Pengaruh Tax Knowledge dan Persepsi Tax Fairness terhadap Tax Compliance Wajib Pajak Badan yang Terdaftar di KPP Madya Bandung.

Damayanti, T. W. \& Supramono. (2012). Apa Kata Mereka? Pengetahuan, Sikap, Niat Patuh Calon Pelaku Pajak. Akuntabilitas Jurnal Ilmiah Akuntansi, 12(114-123).

Damayanti, T. W., Subekti, I., \& Baridwan, Z. (2015). Trust and uncertainty orientation: An efforts to create tax compliance in social psychology framework. Procedia-Social and Behavioral Sciences, 211, 938-944.

James, S., \& Alley, C. (2002). Tax compliance, self-assessment and tax administration. Journal in Finance and Management in Public Services, 2(2), 27-42.

Langham, J. A., Paulsen, N., \& Hartel, C. E. (2012). Improving tax compliance strategies: Can the theory of planned behaviour predict business compliance?. eJournal of Tax Research 10 (2), 364-402.

Niemirowski, P., Baldwin, S., \& Wearing, A. J. (2003). Tax related behaviours, beliefs, attitudes and values and taxpayer compliance in Australia. Journal of Australian Taxation , 6(1), 132.

Nurhayati, N., \& Halimatusadiah, E. (2015). Influence of tax officer service quality and knowledge of tax on individual taxpayer compliance in tax office (kpp) Bojonagara Bandung. International Journal of Applied Research, 1(8), 805-809.

Perpajakan Indonesia: Mekanisme Dan Perhitungan. Yogyakarta: Andi Offset. 
Pope, J., \& Mohdali, R. (2010). The role of religiosity in tax morale and tax compliance. Australian Tax Forum, 25, 565.

Puspita, A. F., Subroto, B., \& Baridwan, Z. (2016). The analysis of individual behaviour of corporate taxpayers' obedience: Tax compliance model (study of hotels in Malang and Batu). Review of Integrative business and economics research, 5(3), 135160.

Reinhart, M., James, S., \& Murphy, K. (2005). Taxpayer beliefs and views: two new surveys. Australian Tax Forum, 20(2), 157188.

Sholihin, M., \& Ratmono, D. (2013). Analysis of SEM-PLS with WarpPLS 3.0 for Nonlinear Relations in Social and Business Research. Yogyakarta: Andi Publisher.

Singh, V., \& Bhupalan, R. (2001). The Malaysian self-assessment system of taxation: Issues and challenges. Tax Nasional, 3, 12-17.
Supramono, \& Damayanti, T. W. (2009).

Tarjo, T., \& Kusumawati, I. (2006). Analisis Perilaku Wajib Pajak Orang Pribadi terhadap Pelaksanaan Self Assessment System: Suatu Studi di Bangkalan. Indonesian Journal of Accounting and Auditing, 10(1).

Trivedi, V. U., Shehata, M., \& Mastelman, S. (2005). Attitudes, Incentives, And Tax Compliance. Canadian Tax Journal / Revue Fiscale Canadienne, 53(1), 29-61.

Ward, S. P., Ward, D. R., \& Wilson Jr, T. E. (1996). The code of professional conduct: Instructional impact on accounting students' ethical perceptions and attitudes. Journal of Education for Business, 71(3), 147-150.

www. pajak.go.id., (2016). Laporan Kinerja Direktur Jendral Pajak. Diakses 10 Januari 2018, dari http://www.pajak.go.id/content/publikasi/LA KINDJP.2016.pdf. 